\title{
Response of rabi Grain Sorghum to Different form of Biofertilizers
}

\author{
T. Bhagavatha Priya ${ }^{1 *}$, B. Gangaiah ${ }^{2}$ and S. Ravi Kumar ${ }^{2}$ \\ ${ }^{1}$ Regional agricultural Research Station, Nandyal, ANGRAU, Guntur, \\ Andhra Pradesh, India \\ ${ }^{2}$ Indian Institute of Millets Research, Rajendranagar, Hyderabad, India \\ *Corresponding author
}

\section{A B S T R A C T}

\section{Keywords}

Azospirillum, Biofertilizers, Liquid biofertilizer, PSB, Rabi, Sorghum

\section{Article Info}

\section{Accepted:}

10 January 2021

Available Online:

10 February 2021
Field studies were conducted during rabi season of 2019-20 under All India Coordinated Sorghum Improvement Project (AICSIP) at Nandyal (Andhra Pradesh) to assess the impact of application of different form of biofertilizers on rabi grain sorghum. The experiment comprising of six treatments $\left(\mathrm{T}_{1}\right.$ : Recommended dose of fertilizer (RDF) alone, $\mathrm{T}_{2}$ : RDF + seed treatment with Azospirillum (Azo.) @ 50g+PSB @ 50g/kg seed, $\mathrm{T}_{3}$ : $\mathrm{RDF}+$ seed treatment with Azo. @ 2ml+PSB @ 2ml/kg seed, $\mathrm{T}_{4}: \mathrm{RDF}+$ seed treatment with Azo. @ 2ml + PSB @ 4ml/kg seed, T 5 RDF + seed treatment with Azo. @ 4ml + PSB @ 2ml/kg seed and $\mathrm{T}_{6}$ : RDF + seed treatment with Azo. @ 4ml+PSB @ 4ml/kg seed) were laid out in Randomized Block Design (RBD) with four replications. The results of the study revealed that seed treatment with Azospirillum and PSB fertilizers were promising to RDF alone from grain yield and net income point of view. Seed treatment with Azospirillum + PSB ( $2 \mathrm{ml}+4 \mathrm{ml} / \mathrm{kg}$ seed $)$ in addition to RDF have enhanced grain and stover yields by $6.22 \%$ and $1.52 \%$ over RDF that together have improved net income by $18.9 \%$. Further with use of the above inoculants in liquid form (Azo. $2 \mathrm{ml}+$ PSB @ 4 $\mathrm{ml} / \mathrm{kg}$ seed) enhancing grain and stover yields by $12.45 \%$ and $0.42 \%$ over powder form of inoculants and have registered Rs. $8014 \mathrm{ha}^{-1}$ higher net income. Liquid form of Azospirillum $2 \mathrm{ml}+\mathrm{PSB} 4 \mathrm{ml} / \mathrm{kg}$ seed have at par performance as that of Azo. $4 \mathrm{ml}+\mathrm{PSB}$ @ $4 \mathrm{ml} / \mathrm{kg}$ seed.

\section{Introduction}

Sorghum (Sorghum bicolor (L.) Moench) is fifth most important cereal of globe (Taylor, 2019) produced in arid and semi-arid regions that are characterised by soil and climate constraints to which major cereals including maize are less well adapted. In India, sorghum grown in rabi season is preferred for human consumption thus has gained prominence to its kharif season. This is evident from the fact that rabi season accounted for $52.7 \%$ of total sorghum grain production of $3.76 \mathrm{~m} \mathrm{t}$ (201819). Low productivity was ascribed to moisture stress that aggravates mineral nutrient stress. The escalating cost of inorganic fertilizers, environmental hazards associated with them and failure in sustaining yields have given way for integrated use of organic and inorganic sources of nutrients, 
which will help to mitigate the abeyance state of soil thus improving biological power of the soil. Sustainable yield levels could be achieved only by the usage of organic source of nutrients and chemical fertilizers. In respect of organic sources of nutrients, biofertilizers form an integral part of nutrient supply system (Sivamurugan et al., 2018). Among bio fertilizers, Azospirillum and phosphate solubilizing bacteria (PSB) are commonly used in crops like sorghum. However, these carriers based powder form inoculants with lower shelf life, low temperature tolerance, low moisture retention capacity and reduced survival, contamination problems etc. were found to result in their reduced effectiveness. In this context, liquid biofertilizers formulation (LBF) was evolved addressing all these concerns (Mahdi et al., 2010). Azospirillum species is known to fix considerable quantity of nitrogen in nonleguminous plants such as cereals, millets, oilseeds, cotton etc. with an estimated 25$30 \%$ chemical nitrogen fertilizer savings. Phosphorus solubilizing bacteria (PSB) was reported to play a vital role in persuading the insoluble phosphatic compound such as rock phosphate, bone meal, basic slag and particularly the chemically fixed soil phosphorus into available form, PSB encourages early root development, produce organic acids like malic, succinic, fumaric, citric, tartaric and alpha ketoglutaric acid which hastens the maturity and thereby increases the ratio of grain to straw as well as the total yield, helps in rapid cell development in plants and consequently enhance disease resistance towards pathogens, increase micro nutrient content in soil like $\mathrm{Mn}, \mathrm{Mg}, \mathrm{Fe}, \mathrm{Mo}$, $\mathrm{B}, \mathrm{Zn}, \mathrm{Cu}$ etc., and make them available to the plant parts; stimulates formation of fats, convertible starches and healthy seeds. Inoculants of phosphate solubilizing bacteria as fertilizer increases $\mathrm{P}$ uptake by the plant and enhance crop yield (Pavan and Satyanarayana, 2012). Azospirillum alone and in combination with PSB were reported to increase yield of sorghum substantially (Patidar and Mali, 2004). Keeping in view the above facts, the present experiment was conducted to study the effect of liquid biofertilizers on growth and yield of rabi grain sorghum when compared to its powder form and no biofertilizer inoculation.

\section{Materials and Methods}

A field experiment was conducted during rabi season of 2019-20 at Regional Agricultural Research Station, Nandyal (Andhra Pradesh). The experiment consisting of six treatments $\left(\mathrm{T}_{1}\right.$ : Recommended dose of fertilizer (RDF) alone (Control), $\mathrm{T}_{2}: \mathrm{RDF}+$ seed treatment with Azospirillum @ 50g + PSB @ 50g/kg seed, $\mathrm{T}_{3}: \mathrm{RDF}+$ seed treatment with Azospirillum @2ml+PSB@2ml/kg seed, $\mathrm{T}_{4}$ : RDF + seed treatment with Azospirillum @ 2ml + PSB@ @ml/kg seed, T $5:$ RDF + seed treatment with Azospirillum @ 4ml+ PSB @ 2ml/kg seed andT $6:$ RDF + seed treatment with Azospirillum @4ml+PSB @ $4 \mathrm{ml} / \mathrm{kg}$ seed) were evaluated in Randomized Block Design (RBD) with four replications. Sorghum cv.CSV-29R was sown with spacing of $45 \mathrm{~cm} \mathrm{x} 15 \mathrm{~cm}$ and recommended dose of fertilizers was applied to soil in each treatment and seeds were treated with both powder and liquid form of biofertilizers (Azospirillum and PSB) at the time of sowing as per treatment. Sorghum growth, yield attributes, grain and stover yields were recorded and economics were worked and all the data was analyzed statistically as outlined by Panse and Sukhatme (1967).

\section{Results and Discussion}

The growth parameters viz., final plant population, plant height and dry matter production at harvest were recorded (Table 1). Higher plant height $(316.4 \mathrm{~cm})$ was recorded by seed treatment with Azospirillum @ 2ml + 
PSB @ 4ml/kg seed which was on par with all other treatments. This might be due to prolonged vegetative growth which increased the plant height. Application of liquid Azospirillum and PSB improve the total biomass significantly over control plot. Significantly higher dry matter production was recorded in seed treatment with Azospirillum @ 2ml + PSB @ 4ml/kg seed $\left(9173 \mathrm{~kg} \mathrm{ha}^{-1}\right)$ and it was statistically on par with use of liquid biofertilizers at higher dose (Azo. @ $4 \mathrm{ml}+$ PSB @ $4 \mathrm{ml}$ ) and the lowest dry matter production was observed in control $\left(8880 \mathrm{~kg} \mathrm{ha}^{-1}\right)$.

Table.1 Growth parameters of rabi grain sorghum as influenced by form of biofertilizers

\begin{tabular}{|c|c|c|c|c|c|}
\hline Treatments & $\begin{array}{c}\text { Final pl } \\
\text { popu } \\
\left(\text { No. } \mathbf{m}^{-2}\right)\end{array}$ & $\begin{array}{c}\text { Plant height } \\
\text { (cm) at } \\
\text { harvest }\end{array}$ & $\begin{array}{c}\text { DMP } \\
\left(\mathrm{kg} \mathrm{ha}^{-1}\right) \text { at } \\
\text { harvest }\end{array}$ & $\begin{array}{c}\text { Days to } \\
50 \% \\
\text { flowering }\end{array}$ & $\begin{array}{l}\text { Days to } \\
\text { maturity }\end{array}$ \\
\hline$T_{1}-100 \%$ RDF (80:40:40 NPK kg ha-1) & 13.2 & 308.9 & 8880 & 67.7 & 110.2 \\
\hline $\begin{array}{l}T_{2}-\text { RDF + Seed treatment with Azospirillum } \\
+ \text { PSB @ } 50 \mathrm{~g} \text { each } / \mathrm{kg} \text { seed }\end{array}$ & 13.7 & 310.6 & 9038 & 68.2 & 110.7 \\
\hline $\begin{array}{l}\mathrm{T}_{3}-\mathrm{RDF}+\text { Seed treatment with } \\
\text { Azospirillum } @ 2 \mathrm{ml}+\mathrm{PSB} @ 2 \mathrm{ml} / \mathrm{kg} \text { seed }\end{array}$ & 14.0 & 314.3 & 9087 & 67.2 & 110.7 \\
\hline 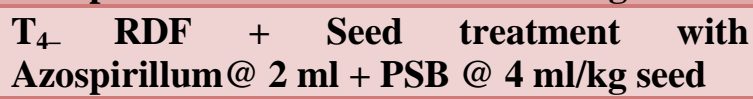 & 14.0 & 316.4 & 9173 & 68.0 & 111.5 \\
\hline $\begin{array}{l}\mathrm{T}_{5} \text { RDF }+ \text { Seed treatment with } \\
\text { Azospirillum @ } 4 \mathrm{ml}+\text { PSB } @ 2 \mathrm{ml} / \mathrm{kg} \text { seed }\end{array}$ & 13.5 & 314.7 & 9125 & 67.7 & 112.5 \\
\hline $\begin{array}{l}\mathrm{T}_{6-} \mathrm{RDF}+\mathrm{Seed} \text { treatment with } \\
\text { Azospirillum } @ 4 \mathrm{ml}+\text { PSB } @ 4 \mathrm{ml} / \mathrm{kg} \text { seed }\end{array}$ & 13.7 & 314.2 & 9147 & 67.2 & 111.2 \\
\hline SEm \pm & 0.26 & 2.96 & 56.77 & 0.39 & 0.71 \\
\hline $\mathrm{CD}(\overline{\mathrm{P}}=\mathbf{0 . 0 5})$ & NS & NS & 172.69 & NS & NS \\
\hline C.V $(\%)$ & 6.82 & 12.89 & 14.25 & 9.16 & 8.28 \\
\hline
\end{tabular}

Table.2 Yield attributes and yield of rabi grain sorghum as influenced by form of biofertilizers

\begin{tabular}{|c|c|c|c|c|c|c|}
\hline Treatments & $\begin{array}{c}\text { Panicle } \\
\text { length } \\
\text { (cm) }\end{array}$ & $\begin{array}{c}\text { Panicle } \\
\text { weight } \\
\text { (g) }\end{array}$ & $\begin{array}{l}1000 \text { seed } \\
\text { weight }(\mathrm{g})\end{array}$ & $\begin{array}{c}\text { Grain } \\
\text { yield } \\
\left(\mathrm{kg} \mathrm{ha}^{-1}\right)\end{array}$ & $\begin{array}{c}\text { Straw } \\
\text { yield } \\
\left(\mathbf{k g ~ h a}^{-1}\right)\end{array}$ & $\begin{array}{c}\text { Harvest } \\
\text { index } \\
(\%)\end{array}$ \\
\hline $\mathrm{T}_{1}-100 \%$ RDF (80:40:40 NPK kg ha-1) & 19.4 & 58.9 & 34.67 & 3171 & 8662 & 26.78 \\
\hline $\begin{array}{l}\mathrm{T}_{2}-\mathrm{RDF}+\text { Seed treatment with } \\
\text { Azospirillum + PSB @ } 50 \mathrm{~g} \text { each } / \mathrm{kg} \text { seed }\end{array}$ & 19.7 & 60.1 & 35.20 & 3314 & 8759 & 27.43 \\
\hline $\begin{array}{l}\mathrm{T}_{3-} \mathrm{RDF}+\text { Seed treatment with } \\
\text { Azospirillum @ } 2 \mathrm{ml}+\mathrm{PSB} @ 2 \mathrm{ml} / \mathrm{kg} \text { seed }\end{array}$ & 20.3 & 64.1 & 35.45 & 3407 & 8717 & 28.09 \\
\hline $\begin{array}{l}T_{4-} \text { RDF + Seed treatment with Azospirillum } \\
\text { @ } 2 \mathrm{ml}+\text { PSB @ } 4 \mathrm{ml} / \mathrm{kg} \text { seed }\end{array}$ & 20.7 & 71.9 & 35.70 & 3774 & 8796 & 28.70 \\
\hline $\begin{array}{l}\mathrm{T}_{5-} \mathrm{RDF}+\mathrm{Seed} \text { treatment with } \\
\text { Azospirillum @ } 4 \mathrm{ml}+\mathrm{PSB} @ 2 \mathrm{ml} / \mathrm{kg} \text { seed }\end{array}$ & 19.7 & 67.4 & 34.95 & 3544 & 8737 & 29.46 \\
\hline $\begin{array}{l}\mathrm{T}_{6}-\mathrm{RDF}+\mathrm{Seed} \text { treatment with } \\
\text { Azospirillum @ } 4 \mathrm{ml}+\mathrm{PSB} @ 4 \mathrm{ml} / \mathrm{kg} \text { seed }\end{array}$ & 19.4 & 68.3 & 35.15 & 3653 & 8788 & 30.04 \\
\hline SEm \pm & 0.62 & 0.76 & 0.20 & 43.53 & 67.19 & 0.25 \\
\hline $\mathrm{CD}(\overline{\mathbf{P}}=\mathbf{0 . 0 5})$ & NS & 2.32 & 0.63 & 132.4 & NS & 0.76 \\
\hline C.V (\%) & 6.30 & 9.34 & 10.18 & 12.50 & 15.35 & 11.78 \\
\hline
\end{tabular}


Table.3 Economics of rabi sorghum as influenced by levels of liquid and powder form of biofertilizers

\begin{tabular}{|c|c|c|c|}
\hline Treatments & $\begin{array}{l}\text { Gross income } \\
\quad\left(\text { Rs. ha }{ }^{-1}\right)\end{array}$ & $\begin{array}{l}\text { Net income } \\
\left(\text { Rs. ha }^{-1}\right)\end{array}$ & B:C ratio \\
\hline $\mathrm{T}_{1}-100 \%$ RDF (80:40:40 NPK kg ha $\left.{ }^{-1}\right)$ & $75826 /-$ & $47723 /-$ & 2.70 \\
\hline $\begin{array}{l}\mathrm{T}_{2}-\mathrm{RDF}+\text { Seed treatment with Azospirillum + PSB } \\
\quad \text { @ } 50 \mathrm{~g} \text { each } / \mathrm{kg} \text { seed }\end{array}$ & 79039/- & $50833 /-$ & 2.80 \\
\hline $\begin{array}{l}\mathrm{T}_{3}-\mathrm{RDF}+\text { Seed treatment with Azospirillum @ } 2 \mathrm{ml} \\
\text { + PSB @ } 2 \mathrm{ml} / \mathrm{kg} \text { seed }\end{array}$ & $81062 /-$ & $52919 /-$ & 2.88 \\
\hline $\begin{array}{l}\mathrm{T}_{4} \text { RDF + Seed treatment with Azospirillum @ } 2 \mathrm{ml} \\
\text { + PSB @ } 4 \mathrm{ml} / \mathrm{kg} \text { seed }\end{array}$ & 86996/- & $58847 /-$ & 3.09 \\
\hline $\begin{array}{l}\mathrm{T}_{5}-\mathrm{RDF}+\text { Seed treatment with Azospirillum @ } 4 \mathrm{ml} \\
\text { + PSB @ } 2 \mathrm{ml} / \mathrm{kg} \text { seed }\end{array}$ & 84090/- & $55913 /-$ & 2.98 \\
\hline $\begin{array}{l}\mathrm{T}_{6}-\mathrm{RDF}+\text { Seed treatment with Azospirillum @ } 4 \mathrm{ml} \\
\text { + PSB @ } 4 \mathrm{ml} / \mathrm{kg} \text { seed }\end{array}$ & $86518 /-$ & $58335 /-$ & 3.07 \\
\hline
\end{tabular}

Seed inoculation with liquid biofertilizers fixes nitrogen and solubilizes insoluble phosphate in soil and make available to plants due to which plant grows vigorously producing more biomass (Sandhyarani et al, 2019). Days to $50 \%$ flowering and days to maturity were not significantly influenced by form of bio fertilizers. Grain, stover yield and economics of rabi grain sorghum varied significantly among the bio fertilizer treatments (Table $2 \& 3$ ). Maximum panicle weight $(71.9 \mathrm{~g}), 1000$ seed weight $(35.7 \mathrm{~g})$ and harvest index (28.9\%) were recorded under seed treatment with Azospirillum @ $2 \mathrm{ml}+$ PSB @ $4 \mathrm{ml} / \mathrm{kg}$ seed. Application of liquid biofertilizers and its seed inoculation significantly increased the respective yield parameters over control plot. The use of biofertilizers may lead to higher availability of nitrogen and phosphorus that promoted growth and development and ultimately resulting in higher yield parameters and yield (Baghchand and Gautam, 2000).

Seed treatment with Azospirillum @ 50g + PSB @ 50g $/ \mathrm{kg}$ seed significantly improved stover yields $\left(8759 \mathrm{~kg} \mathrm{ha}^{-1}\right)$ over no biofertilizer control (RDF) treatment (8662 $\mathrm{kg} / \mathrm{ha}$ ). Grain yields too showed increasing trend due to seed treatment with powder form of bio fertilizers, the increase was statistically insignificant over control (3171 kg/ha). Use of liquid biofertilizer inoculants (Azo. @ $2 \mathrm{ml}$ + PSB @ $4 \mathrm{ml})$ being at par with its other three rates (Azo. @ 2 ml + PSB @ 2 ml; Azo. @ $4 \mathrm{ml}+$ PSB @ $2 \mathrm{ml}$ and Azo. @ $4 \mathrm{ml}+$ PSB@4 ml) have brought significant improvement in grain yield (3774 $\mathrm{kg} \mathrm{ha}^{-1}$ ) over powder form inoculants i.e. Azospirillum @ 50g + PSB @ 50g/kg (3314 kg ha ${ }^{-1}$ ). Stover yields remained unaltered statistically with use of liquid form of biofertlizers as compared to its powder form. Liquid biofertilizers treated sorghum (mean over 4 rates) has $12.45 \%$ and $0.42 \%$ higher grain and stover yields than its powder form (Azospirillum @ 50g+PSB @ $50 \mathrm{~g} \quad / \mathrm{kg}$ ) treatment. Grain (3774 $\mathrm{kg} \mathrm{ha}^{-1}$ ) and stover yields $\left(8759 \mathrm{~kg} \mathrm{ha}^{-1}\right)$ were maximum with Azospirillum@2 ml+PSB @ 4 ml/kg seed treatment (Table 2). Higher yields of powder and liquid form of Azospirillum and PSB biofertlizer inoculated sorghum crop of present were supported findings of Jat et al., (2013) and Raja and Takankharb (2017). Increased availability of nitrogen and phosphorus with liquid biofertilizers has enhanced the efficacy that might have promoted growth, yield attributes formation and thus higher yields. 
Seed treatment with biofertilizers irrespective of its form (powder or liquid) have brought marked improvements in net income (Table 3). Seed treatment with Azospirillum @ $50 \mathrm{~g}$ + PSB @ 50g $/ \mathrm{kg}$ seed has improved net income by Rs. 3110/- as compared to RDF i.e. no bio fertilizer control (Rs.47723 $\mathrm{ha}^{-1}$ ). The net income of sorghum crop were further improved by Rs. 6735 with use of liquid form Azospirillum and PSB for seed treatment. Among liquid bio fertilizer inoculant levels, Azospirillum @2 ml + PSB @ 4 ml/kg seed being at par with Azospirillum @ $4 \mathrm{ml}+$ PSB @ $4 \mathrm{ml} / \mathrm{kg}$ seed has recorded highest net income (Rs. $58847 \mathrm{ha}^{-1}$ ) and B:C ratio (3.09). These results are in conformity with the findings of Patel (2015). Higher net income and BC ratio in liquid bio fertilizer inoculation(Azospirillum @ $2 \mathrm{ml}+$ PSB @ 4 $\mathrm{ml} / \mathrm{kg}$ seed) was ascribed to higher grain and stover yields.

Based on the present study it was recommended that for rabi grain sorghum seed treatment with Azospirillum + PSB irrespective of its form (liquid or powder) is promising to the existing use of recommended dose of fertilizers (RDF) alone. Liquid form bioincoulants i.e. Azospirillum $2 \mathrm{ml}+$ PSB @ $4 \mathrm{ml} / \mathrm{kg}$ seed is promising to its powder form of inoculation from grain, stover yield and net returns point of view and are recommended for adoption in lieu of current practice of use of RDF alone.

\section{Acknowledgements}

The experiment was conducted at the State Agricultural University (SAU) centre as a part of the All India Coordinated Research Project on Sorghum (AICRPS) and the Indian Institute of Millets Research (IIMR), Hyderabad. Authors acknowledge Indian Council of Agricultural Research (ICAR) for funding these long term networks.

\section{References}

Baghchand and Gautam, R.C. 2000. Effect of organic manure, biofertilizers and inorganic fertilizer on growth, yield and quality of rainfed pearl millet. Annals of Agriculture Research. 21: 459-464.

Jat, M.K., Purohit, H.S., Bahadur Singh, Garhwal, R.S and Mukesh Choudhary. 2013. Effect of integrated nutrient management on yield and nutrient uptake in sorghum (Sorghum bicolor). Indian Journal of Agronomy, 58 (4): 543-547.

Mahdi, S.S., Hassan, G.I., Samoon, S.A., Rather, H.A and Dar, S.A. 2010. Biofertilizers in organic agriculture. Journal of Phytology, 2: 42-54.

Panse, V. G and Sukhatme, P. U. 1967. Statistical Methods for Agricultural Workers. ICAR, New Delhi.

Patel, B.K. 2015. Effect of land configuration and integrated nutrient management on productivity of different varieties of sorghum (Rabi) grown on fluventicustochepts. Ph.D. thesis submitted to NAU, Navsari (Gujarat).

Patidar, M and Mali, A.L. 2004. Effect of farmyard manure, fertility levels and Bio- fertilizer on growth, yield and quality of sorghum (Sorghum bicolor). Indian Journal of Agronomy. 49(2): 117-120.

Pavan, K.P and Satyanarayana, S.D.V. 2012. Liquid Microbial Consortium- A Potential Tool for Sustainable Soil Health. Journal of Biofertilizers \& Biopesticides. 3 (124): 1-9.

Raja, D and Takankharb, V.G. 2017. Effect of Liquid biofertilizers (Bradyrhizobium and PSB) on availability of nutrients and soil chemical properties of Soybean (Glycine max L.). International Journal of Pure and Applied Bioscience. 5 (5): 88-96.

Sandyarani, K., Satish, P., Sudha Rani, C and 
Sudhakar, C. 2019. Effect of Liquid Biofertilizers on Growth and Yield of Rabi Sorghum (Sorghum bicolor L.). Chemical Science Review and Letters. 8 (32): 190-194.

Sivamurugan, A.P., Ravikesavan, R., Singh, A.K and Jat, S.L. 2018. Effect of different levels of $\mathrm{P}$ and liquid biofertilizers on growth, yield attributes and yield of maize. Chemical Science Review and Letters, 7(26): 520-523.

Taylor, John R.N. 2019. Sorghum and Millets: Taxonomy, History, Distribution, and Production. In: John R.N. Taylor and Kwaku G. Duodu, Editor(s), Sorghum and Millets (Second Edition), AACC International Press, pp. $1-21$.

\section{How to cite this article:}

Bhagavatha Priya, T., B. Gangaiah and Ravi Kumar, S. 2021. Response of rabi Grain Sorghum to Different form of Biofertilizers. Int.J.Curr.Microbiol.App.Sci. 10(02): 945-950. doi: https://doi.org/10.20546/ijcmas.2021.1002.112 